\title{
Assessment of Land Cover Change in the North Eastern Nigeria 1986 to 2005
}

\author{
Samuel Garba ${ }^{1} \&$ Tim Brewer ${ }^{2}$ \\ ${ }^{1}$ Department of Civil and Water Resources Engineering, University of Maiduguri, Maiduguri, Nigeria \\ ${ }^{2}$ Environmental Science and Technology Department, Cranfield University, Cranfield, UK \\ Correspondence: Samuel Garba, Department of Civil and Water Resources Engineering, University of Maiduguri, \\ Maiduguri, Nigeria. Tel: 234-708-979-8044. E-mail: sam.garba@yahoo.com
}

\author{
Received: September 7, 2013 Accepted: November 11, 2013 Online Published: November 22, 2013 \\ doi:10.5539/jgg.v5n4p94 \\ URL: http://dx.doi.org/10.5539/jgg.v5n4p94
}

\begin{abstract}
Environmental disturbance such as drought, overgrazing, and increase in population in north eastern Nigeria over the years has led to degradation, shortage of land and water resources and sometimes violent conflict among communities. Land cover change provides a vital means of understanding and managing these problems. Thus this research provided an assessment of how tree, shrub grass, bare ground and urban land cover changed from 1986 to 2005. NigeriaSat-1 and Landsat images were used with data obtained from field survey for the land cover classifications. Change in the land covers were analysed according to persistence, swapping, net loss and gain. Uncertainties were analysed by confusion matrices. The overall accuracies of the classifications used for the analysis are between $60 \%$ and $75 \%$. The transition and change accuracies are between $45 \%$ and $60 \%$. Approximately $60 \%$ of the area of study remained unchanged during the period. Of the remainder, approximately $11 \%$ of the area interchanged between shrub grass and bare ground. The most unstable category was shrub grass and was also the source of misclassification. The changes in general concurred with the perception of change in the area and gave some insight on the change that occurred.
\end{abstract}

Keywords: land cover, arid, persistence, swapping, confusion matrix

\section{Introduction}

The Sahelian region is experiencing unprecedented environmental changes in land cover and land quality (Onyewotu et al., 2003; Foley et al., 2003; Lambin et al., 2001). The changes emanate from the way humans put their land to use and from climatic variability, for example, drought. This has led to desert like conditions in several areas of northern Nigeria causing loss of arable and grazing land and consequently population migration, conflict over the limited resources and economic loss to the people in the area.

The government of Nigeria is concerned with the development of policies and infrastructure that will mitigate the negative impacts of the environmental changes. These need to be based on good science rather than on false or simplistic theories or assumed estimates, as has been the case many times in the past (Milligan \& Binns, 2007; Lambin et al., 2001). Therefore this research was conducted in order to critically assess changes in historic and current land cover in north east Nigeria using remote sensing methods, and thus provides data for the management of natural resources which could aid the mitigation of negative impacts of land use change and climatic variability.

Land cover is an important indicator of environmental change and plays a role in the process of change (Lambin et al., 2006; Moran et al., 2004; Lambin et al., 2001). Land cover represents the physical attributes of the earth surface such as the various types of vegetation cover and urban settlement. In Nigeria land cover data for natural resource management is lacking and where they do exist they are out of date (Shonenka, 1997). Thus because of the lack of such data, professionals such as town planners and resource managers often make decisions based on false assumptions (Abdalla, 1994). Previous attempts to generate such data for north eastern Nigeria were by Abdalla (1994) and Lawan (1996). Their work was however limited to the neighbourhood of the River Komadugu, and thus may not be representative of all physiographic regions in north eastern Nigeria.

Presently remote sensing methodologies provide the most current and viable means of obtaining land cover data (Ramankutty et al., 2006). The availability and continuous affordability of satellite data at global, 
regional and local scale makes the remote sensing method viable and hence the means of evaluating the changes occurring in the environment. The launch of the NigeriaSat-1 satellite in September 2003 demonstrates the importance that the Nigerian government gives to the acquisition of environmental data by remote sensing.

\section{Method}

\subsection{Location of Study}

A manageable area limited to $100 \mathrm{~km}$ by $50 \mathrm{~km}$ that fell across the Sudano-Sahelian region of Yobe state was chosen as being representative of north eastern Nigeria (Figure 1). The area has two climatic seasons: the wet season between June and September and the dry season for the rest of the year. Annual rainfall records show an average of $410 \mathrm{~mm}$ from June to October in Garin Alkali north of the study area, $620 \mathrm{~mm}$ in Potiskum within the study area and at Fika, which is slightly south of the study area, $600 \mathrm{~mm}$ for the same period (Yobe state Ministry of Agriculture, 2005).

The study area was divided into four physiographic areas (Figure 1). The Gamawa-Jakusko plain, named after the two major towns slightly north of the study area, lies between the two tributaries of the Komadugu-Yobe river. The second area was named the Fadama being the flood plain of the River Komadugu gana. The river normally flows from Kari from June to August and with the water passing through the study area between October and December on its way to Lake Chad (Goes, 2005). The third area, the Potiskum plain, lies between the Fadama and Gudi-Jonga hills. This area has the largest urban centre in the study area. The Gudi Jonga hills in the southern part are hilly and with higher vegetation density. Each of the areas in some way represents north eastern Nigeria: the dry north closer to the Sahara in the Gamawa-Jakusko plain, the Gudi-Jonga hills in the south representing the savannah region, the Fadama representing the areas with rivers and their neighbour, while the Potiskum plain the transition zone between the Sahel and the Savannah.

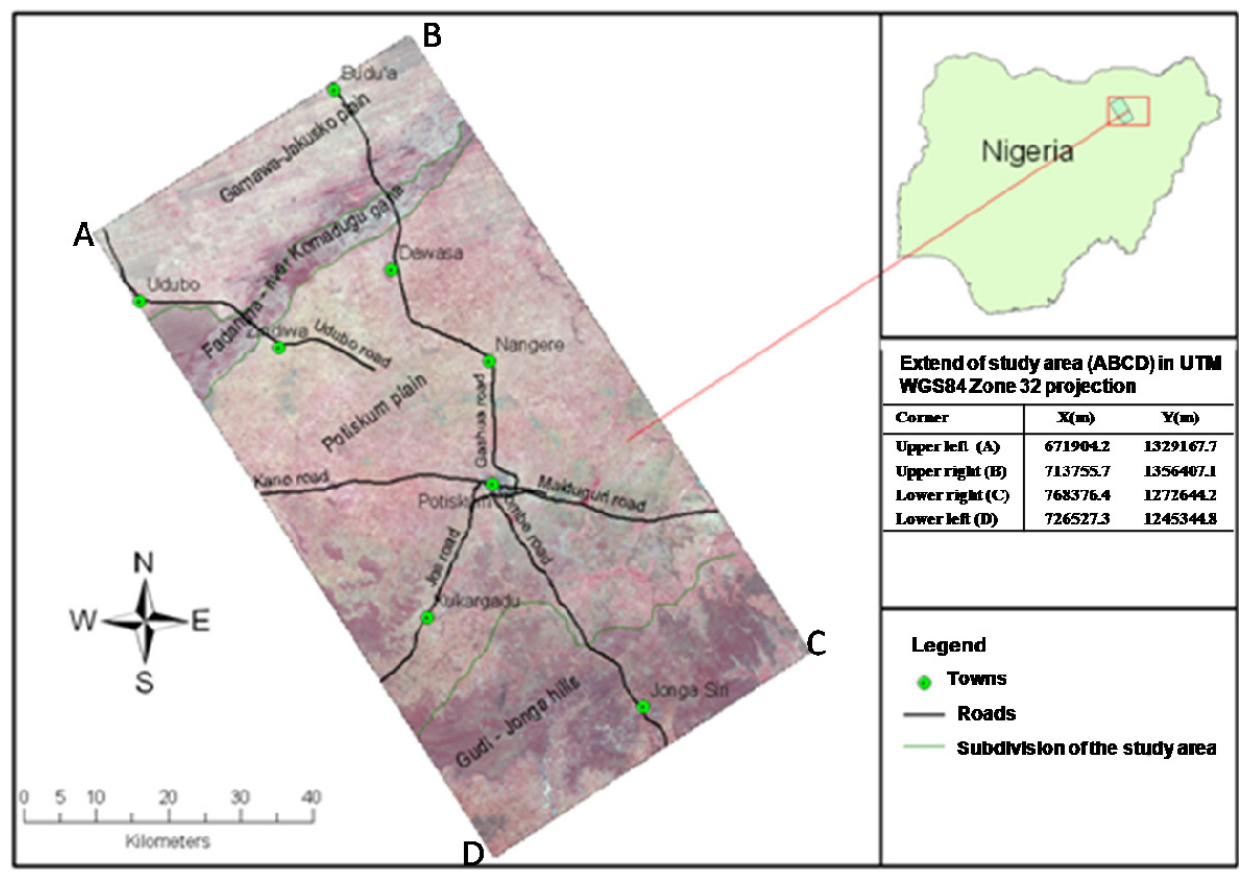

Figure 1. The four physiographic regions of the study area (Gamawa-Jakusko plain, Fadama, Potiskum plain and Gudi-Jonga hills)

\subsection{Method of Assessing the Land Cover Change}

Changes assessment was conducted on four land cover types: trees, shrub grass, bare ground and urban land covers from 1986 to 2005. The assessment was done by first classifying the NigeriaSat-1 image of 2005 and subsequently the Landsat data from 2000 and 1986. The classification was preceded by a field survey that provided material for training the classifiers and assessing the accuracy of the classifications. An evaluation of each land cover was conducted and analysed over the period of the study. 
The land cover types assessed were selected according to what was encountered during the field survey and what was classifiable with the NigeriaSat-1 and the Landsat data used. They are also a modification of the previous work by Abdalla (1994), Lawan (1996) and also the Africover project (FAO-Africover, 2007). Thus tree refers to a community of vegetation where there are more than $40 \%$ trees with heights on average $3 \mathrm{~m}$ and above; shrub grass defined the community of intermingled shrubs and grasses and where the tree community does not dominate (less than $40 \%$ cover); bare ground refers to land without vegetation cover at the time of image acquisition; and urban refers to urban settlement. Water refers to body of water such as lake, river or pond.

The change in both tree and shrub grass (i.e. the biomass) would affect the quantity of carbon on the ground and in the atmosphere and hence the climate (Lambin et al., 2006; Trumper et al., 2008). The reduction of biomass also affects grazing area, which may result in overgrazing and arguably (Lambin et al., 2001) degradation (Trumper et al., 2008). The reduction of the tree to shrub grass would also indicate loss in biomass, and where there were changes in the dominance of tree to shrub grass there would be a change from savannah to grassland. The increase in bare ground might suggest an increase in agricultural land, and depending on the type of management affect carbon sequestration or release (which could cause degradation). The increase in urban land cover would indicate population increase naturally or by migration and the expansion of land use. These changes relate to desertification and drought affecting the area.

\subsection{The Satelite Imagery Used and Registration}

The NigeriaSat-1 image used was acquired on the $11^{\text {th }}$ November 2005. It has three wavebands: $0.52-0.62$, green; $0.63-0.69$, red; and 0.77-0.90, infrared (DMC, 2007). These wavebands and wavelengths are similar to their equivalent bands in the Landsat data. The two other images used were Landsat images acquired on $23^{\text {rd }}$ October 2000 (Landsat ETM+) and the $9^{\text {th }}$ October 1986 (Landsat TM). All the images were acquired during the dry season and were assumed to be under approximately the same climatic condition.

The three sets of images were geometrically matched automatically (Pan et al., 2008; Chen et al., 2007; Stow et al., 2003), the Landsat data were acquired as orthorectified images (Landsat, 2004) and used as the reference to georeference the NigeriaSat-1 image. This method was preferred over manual georeferencing in order to deal with the difficulty of finding suitable tie points on the images. The Erdas Imagine Imagine Autosync algorithm (Leica Geosystems Geospatial Imaging LLC, 2006) was used, and it automatically generated 101 tie points with an overall root mean square error (RMSE) of 1.54 pixels, about $50 \mathrm{~m}$.

\subsection{Field Survey}

Most of the field survey was undertaken during the same dry season as the acquisition of the NigeriaSat-1 image, there were a few sample squares surveyed in June but before the rainfall began that year in the study area. The design of the survey involved an unaligned systematic sampling procedure (Taylor et al., 1997; Gallego, 1995), in which a $1 \mathrm{~km}$ square was randomly selected within every $10 \mathrm{~km}$ by $10 \mathrm{~km}$, thus 50 one kilometre squares were randomly selected. The area covered by the sample squares amounted to $1 \%$ of the study area which is similar to Sannier (2000). Images corresponding to the sample squares were subset from the NigeriaSat-1 image to create 1:10,000 scale hardcopy field documents. Using an acetate overlay the boundaries of land covers were plotted after determining the location of the square in the field using a hand held Global Positioning System (GPS). The results from the field survey were subsequently digitised.

\subsection{Creation of Reference Data for Classificattion}

The field survey data became the reference data for the classification of the 2005 image.

There was no reference data that corresponded to the historical Landsat data and the disparity of time between the field survey and the acquisition of the images rendered the acquired field survey data unsuitable for the classification of the 1986 and 2000 images. Surrogate ground truth was derived by visual image interpretation procedures (Lillesand et al., 2008) to develop a reference data for the historical data. Interpretation keys were developed for each land cover from the 2005 image. The keys and overall patterns of a land cover type in relation to its neighbourhood and personal knowledge of the area were used to refine the interpretation keys for each land cover for the two years using false colour composites of the images and the normalised difference vegetation index (NDVI) (Jensen, 2000; Sannier, 2000; Wagenseil \& Samimi, 2006). The use of patterns and shapes was based on the assumption that features on the images that retained their shape and pattern are likely to be the same land cover since land covers tend to persist rather than change (Pontius et al., 2004) unless proven otherwise by other image characteristics such as the NDVI. The corresponding locations of all the 2005 sample squares were interpreted for the 2000 and 1986 images. 


\subsection{Classification and Accuracy Assessment}

Part of the reference data was used to train and conduct classification using a combined parallelepiped and maximum likelihood classifier (Schowengerdt, 2007; Richards \& Jia, 1999) using the Erdas Imange software (Leica Geosystems Geospatial Imaging LLC, 2006). The combination produced a better overall accuracy in arid and semi arid zones (Garba, 2008; Alrababah \& Alhamad, 2006), as well as. Pixels were selected from across the sample squares representing particular land covers to develop spectral signatures. The spectral signatures are statistical parameters such as mean and the covariance of the pixels selected to represent each land cover.

The other part of the field data was used to test the accuracy of the classification using the confusion matrix approach (Congalton \& Green, 1999; Pontius, 2000; Lillesand et al., 2008). The classifications produced thematic maps from which area calculations of each of the land cover could be made using pixel counting. The confusion matrix produced showed the degree to which the classified image agreed with the reference data and how well each of the land cover types was classified and the difficulty in separation between the land covers (Congalton \& Green, 1999).

The analysis of land cover change followed the classification (Coppin et al., 2004). These changes were analysed according to the loss and gain of each land cover category and according to 'persistence' and 'swapping' of a land cover (Pontius et al., 2004). Persistence refers to land cover that persisted from one time to another without changing and swapping refers to the swapping of a land cover from one location in year 1 to another in the year 2. Thus swapping provides an explanation to the quantity of land cover change between two years after accounting for persistence and net loss or gain, this quantity would be the same in the two years used in the computation hence it is computed as the sum of the areas in the two years used in the computation (Pontius et al., 2004).

\subsection{Field Interview}

Group interviews ( 3 to 8 older men, 50 years old and above) were conducted across the study area at 40 locations with the objective of determining how people in the study area felt about the environmental changes going on around them. Each interview was unstructured and was based on simple questions as to what they thought existed in terms of land cover in their areas some 30 years ago, whether there was forest or not, whether there were changes over time, what they thought had caused the changes and what they thought were the consequences? Further questions on the consequences included the migration and immigration of people, conflict with nomads and any other related issues they felt were important.

\section{Results}

The field survey was undertaken according to plan with all the 50 sample squares visited in 21 days. Locating some of the squares was the most difficult aspect of the field survey. These squares were usually more than $5 \mathrm{~km}$ away from major roads and because there was no current topographic map of the area, there was difficulty in navigating to the squares. Thus, local assistance was sought to help find the squares. This procedure adds to the difficulty and cost of field survey.

\subsection{Classifications of 2005, 2000 and 1986 Imageries}

The classifications produced three thematic maps (Figure 2). These generally showed that the tree land cover dominated the fadama area and the southern part of the study area, bare ground dominated the Gamawa-Jakusko plain and the northern part of the Potiskum plain, and shrub grass dominated the southern part of the Potiskum plain and formed a mosaic with the tree land cover in both the Fadama and the Gudi-Jonga hills. The greatest visual changes were seen in the northern part of the study area. 


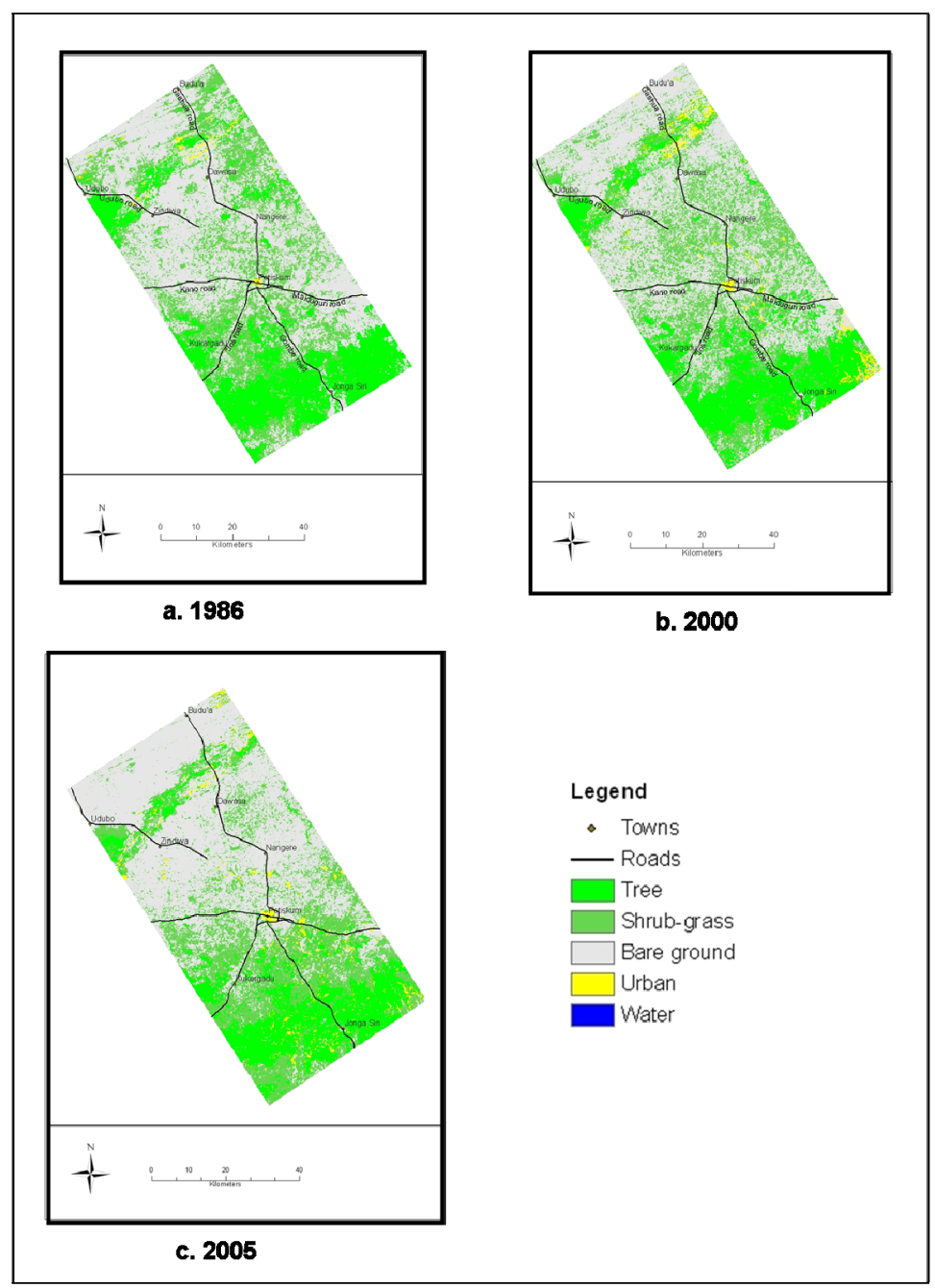

Figure 2. The result of the classification according to tree, shrub grass, bare ground, urban and water in the images of: a. Landsat TM (1986); b. Landsat ETM+ (2000) and c. NigeriaSat-1(2005)

\subsection{Accuracies of the Classifications}

The classifications have overall accuracies (Congalton \& Green, 1999; Pontius, 2000; Lillesand et al., 2008) of $63 \%$ in $2005,67 \%$ in 2000 and $71 \%$ in 1986 (Tables $2-3$ ).

These accuracies are similar to thematic maps produced using a similar methodology such as, Sannier (2000), Foody (2002) and Foody (2006).The producer accuracies of all the land covers were over $60 \%$ in the three years of classification except the shrub grass in 2000 and 2005. The user accuracies of the shrub grass of 1986 and 2005, and urban land cover of 2000 and 2005 are also lower the $60 \%$ (Tables 2-3). The shrub grass showed a pattern of decline from 1986 to 2005 an indication of unstable conditions and modification within the land cover class, and difficulty arising from identifying the transformation of the tree class to shrub grass and the shrub grass to bare ground. In the case of the urban land cover, poor user accuracies were due to classification of some areas of the tree cover as urban. 
Table 1. Confusion matrix for the NigeriaSat-1 2005 image classification

\begin{tabular}{|c|c|c|c|c|c|c|c|}
\hline \multicolumn{8}{|c|}{ Reference } \\
\hline & & Tree & Shrub- grass & Bare ground & Urban & Row Total & User Accuracy (\%) \\
\hline \multirow{4}{*}{ 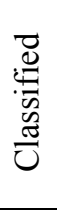 } & Tree & 515 & 213 & 56 & 0 & 784 & 65.69 \\
\hline & Shrub grass & 88 & 640 & 405 & 4 & 1137 & 56.29 \\
\hline & Bare ground & 15 & 385 & 952 & 12 & 1364 & 69.79 \\
\hline & Urban & 20 & 42 & 39 & 62 & 163 & 38.04 \\
\hline & Column Total & 638 & 1280 & 1452 & 78 & 3448 & \\
\hline & Producer Accuracy $(\%)$ & 80.72 & 50.00 & 65.56 & 79.49 & & \\
\hline & Dverall Accuracy (\%) & 62.91 & \multicolumn{2}{|c|}{ Kappa $(\%)=44.46$} & \multicolumn{3}{|c|}{ Variance $($ kappa $)=0.0002$} \\
\hline
\end{tabular}

Table 2. Confusion Matrix for the Landsat ETM+ year 2000 image classification

\begin{tabular}{|c|c|c|c|c|c|c|c|c|}
\hline \multicolumn{9}{|c|}{ Reference } \\
\hline & & Tree & $\begin{array}{l}\text { Shrub } \\
\text { grass }\end{array}$ & $\begin{array}{l}\text { Bare } \\
\text { ground }\end{array}$ & $\begin{array}{c}\text { Urba } \\
n\end{array}$ & $\begin{array}{c}\text { Wate } \\
\mathrm{r}\end{array}$ & $\begin{array}{l}\text { Row } \\
\text { Total }\end{array}$ & $\begin{array}{c}\text { User Accuracy } \\
(\%)\end{array}$ \\
\hline \multirow{5}{*}{ 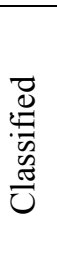 } & Tree & 402 & 151 & 32 & 1 & 1 & 587 & 68.48 \\
\hline & Shrub grass & 139 & 669 & 299 & 4 & & 1111 & 60.22 \\
\hline & Bare ground & 9 & 374 & 1184 & 4 & & 1571 & 75.37 \\
\hline & Urban & 7 & 23 & 75 & 61 & & 166 & 36.75 \\
\hline & Water & 4 & 4 & 5 & & 0 & 13 & 0.00 \\
\hline & Column Total & 561 & 1221 & 1595 & 70 & 1 & 3448 & \\
\hline & $\begin{array}{c}\text { Producer Accuracy } \\
(\%)\end{array}$ & $\begin{array}{c}71.6 \\
6\end{array}$ & 54.79 & 74.23 & 87.14 & 0.00 & & \\
\hline \multicolumn{2}{|c|}{ Overall Accuracy (\%) } & $\begin{array}{c}67.1 \\
7\end{array}$ & \multicolumn{3}{|c|}{ Kappa $(\%)=49.21$} & \multicolumn{3}{|c|}{ Variance $($ kappa $)=0.0002$} \\
\hline
\end{tabular}

Table 3. Confusion Matrix for the Landsat TM 1986 image classification

\begin{tabular}{|c|c|c|c|c|c|c|c|c|}
\hline \multicolumn{9}{|c|}{ Reference } \\
\hline & & Tree & $\begin{array}{c}\text { Shrub } \\
\text { grass }\end{array}$ & $\begin{array}{l}\text { Bare } \\
\text { ground }\end{array}$ & Urban & Water & $\begin{array}{l}\text { Row } \\
\text { Total }\end{array}$ & $\begin{array}{c}\text { User } \\
\text { Accuracy } \\
(\%)\end{array}$ \\
\hline \multirow{5}{*}{ 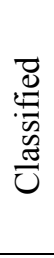 } & Tree & 505 & 164 & 29 & 3 & 3 & 704 & 71.73 \\
\hline & Shrub grass & 99 & 693 & 436 & 9 & 1 & 1238 & 55.98 \\
\hline & Bare ground & 5 & 259 & 1160 & 1 & & 1425 & 81.40 \\
\hline & Urban & 0 & 2 & 3 & 68 & & 73 & 93.15 \\
\hline & Water & 0 & 2 & & & 6 & 8 & 75.00 \\
\hline & $\begin{array}{l}\text { Column Total } \\
\text { Producer }\end{array}$ & 609 & 1120 & 1628 & 81 & 10 & 3448 & \\
\hline & Accuracy $(\%)$ & 82.92 & 61.88 & 71.25 & 83.95 & 60.00 & & \\
\hline $\mathrm{Ov}$ & all Accuracy (\%) & 70.53 & \multicolumn{3}{|c|}{ Kappa $(\%)=54.78$} & \multicolumn{3}{|c|}{ Variance $($ kappa $)=0.0001$} \\
\hline
\end{tabular}

\subsection{Analysis of Change}

The land covers areas that persisted without change (given by the sum of the diagonal) between 1986 and 2000, was 309,530 ha or $61 \%$ of the study area (Table 4, circular braket) and between 2000 and 2005 was 322,813 ha or $64 \%$ of the study area (Table 5, circular braket). Between 1986 and 2000, 15\%, 13.6\% and $32.1 \%$ of the study 
area remained as tree, shrub grass and bare ground, respectively. Approximate land area that persistence of the land covers can be seen between 2000 and 2005 (Table 5). The bare ground is thus the dominant and most persistent land cover. By $2000,4.9 \%$ of the study area converted to the tree land cover but $6.3 \%$ of the study area that was tree converted to another land cover giving a net loss of $1.4 \%$. Similarly, $20.5 \%$ of the area that was shrub grass in 1986 became other land covers and $13.8 \%$ of the study became shrub grass. In the case of bare ground, by $200011.1 \%$ of the study area bare ground became other land cover and $16.8 \%$ of the study area became shrub grass. The conversion in relation to bare ground is mostly with shrub grass (Table 4). By 2005, the net loss in the tree land cover continued but the shrub grass and the bare ground had net gains. The water and urban categories were left out of the analyses because their quantities were small and had poor user accuracies (Tables 2-3).

According to Tables 4 and 5, the tree class had a net loss of about 7,000 ha (1.4\% of the study area) between 1986 and 2000, i.e. about 500 ha annually. Similarly, there was a net lost of about 17,000 ha between 2000 and 2005, i.e. 3,000 ha annually. The shrub grass experienced a net loss of 34,000 ha between 1986 and 2000 i.e. 2500 ha annually, but a net gain of 11,500 ha between 2000 and 2005 i.e. 2300 ha annually. The bare ground had a net increase of 29,000 ha and 7,000 ha i.e. annual rates of 2000 ha and 1400 ha in the first period and second period respectively. The net loss in the tree which increased between 2000 and 2005 indicates the degradation in biomass a pointer to the increase in desertification and drought in the area. The increase in the shrub grass nevertheless may not contradict the environmental degradation suggested because of the high rate of conversion between the shrub grass and the bare ground which creates uncertainties in the quantification of the shrub grass change (as evident in the poor classification). The swap analysis between 1986 and 2000 showed that $9.8 \%$ (Table 4) or 24,757 ha of tree was lost in 1986 but gained in 2000 in another location, similarly $27.6 \%$ or 69,000 ha of shrub grass and $22 \%$ or 55,577 ha of bare ground was lost and gained between these two years. The swaps between 2000 and 2005 were $6.4 \%$ (tree), 28.8\% (shrub grass) and 25\% (bare ground) (Table 5). The trend in the swap analysis is similar to the changes in the net losses or gains between 1986-2000 and 2000-2005. Thus the larger changes occurring in the shrub grass and the bare ground are within the land cover at different locations.

Tables 4 and 5 further provide the transition of each land cover to the other land cover (as represented by the square bracket), the values in the square bracket shows how a particular land cover in the previous time of classification has been distributed in the second time. For example, whatever was tree in 1986 (Table 4), 71\% remained tree by 2000 and $18 \%, 7 \%$ and $4 \%$ became shrub grass, bareground and urban respectively. The tree and the bare ground show a high percentage of persistence, the shrub grass had over $40 \%$ persistence and Urban a lower percentage both the two periods (Tables 4 and 5). 
Table 4. Land cover transition matrix 1986 to 2000 in hectares and percentages

\begin{tabular}{|c|c|c|c|c|c|c|}
\hline \multicolumn{7}{|c|}{$2000 \downarrow$} \\
\hline $1986 \rightarrow$ & Tree & $\begin{array}{l}\text { Shrub } \\
\text { grass }\end{array}$ & $\begin{array}{l}\text { Bare } \\
\text { ground }\end{array}$ & Urban & Water & Total (1986) \\
\hline Tree (ha) & $\begin{array}{c}76,252 \\
(15.1) \\
{[71]}\end{array}$ & $\begin{array}{c}19,392 \\
(3.8) \\
{[18]}\end{array}$ & $\begin{array}{c}7,554 \\
(1.5) \\
{[7]}\end{array}$ & $\begin{array}{c}4,818 \\
(1) \\
{[4]}\end{array}$ & 477 & $\begin{array}{c}108,493 \\
(21.4)\end{array}$ \\
\hline Shrub grass (ha) & $\begin{array}{c}19,209 \\
(3.8) \\
{[11]}\end{array}$ & $\begin{array}{c}68,781 \\
(13.6) \\
{[40]}\end{array}$ & $\begin{array}{c}76,181 \\
(15.1) \\
{[44]}\end{array}$ & $\begin{array}{c}8,227 \\
(1.6) \\
{[5]}\end{array}$ & 198 & $\begin{array}{c}172,595 \\
(34.1)\end{array}$ \\
\hline Bare ground (ha) & $\begin{array}{c}3,801 \\
(0.8) \\
{[2]}\end{array}$ & $\begin{array}{c}49,044 \\
(9.7) \\
{[23]}\end{array}$ & $\begin{array}{c}162,111 \\
(32.1) \\
{[74]}\end{array}$ & $\begin{array}{c}2,821 \\
(0.6) \\
{[1]}\end{array}$ & 31 & $\begin{array}{c}217,807 \\
(43.2)\end{array}$ \\
\hline Urban (ha) & $\begin{array}{l}1,441 \\
(0.3) \\
{[24]}\end{array}$ & $\begin{array}{c}1,394 \\
(0.3) \\
{[23]}\end{array}$ & $\begin{array}{c}909 \\
(0.2) \\
{[15]}\end{array}$ & $\begin{array}{c}2,337 \\
(0.5) \\
{[38]}\end{array}$ & 77 & $\begin{array}{l}6,159 \\
(1.3)\end{array}$ \\
\hline Water (ha) & $79(0)$ & $14(0)$ & $11(0)$ & $37(0)$ & $49(0)$ & 190 \\
\hline Total & $\begin{array}{c}100,782 \\
(20)\end{array}$ & $\begin{array}{c}138,625 \\
(27.4)\end{array}$ & $\begin{array}{c}246,766 \\
(48.9) \\
\end{array}$ & $\begin{array}{c}18,239 \\
(3.7) \\
\end{array}$ & 831 & $\begin{array}{c}505,244 \\
100 \\
\end{array}$ \\
\hline $\begin{array}{c}\text { Swap } \\
\text { Net Gain by } 2000\end{array}$ & $(9.8)$ & $(27.6)$ & $\begin{array}{l}(22) \\
(5.7)\end{array}$ & $\begin{array}{l}(1.6) \\
(2.4)\end{array}$ & & \\
\hline Net lost by 2000 & (1.4) & $(6.7)$ & & & & \\
\hline
\end{tabular}

Note: The values in the circular bracket are percentage values of the area of study, and values in square bracket are percentage values convert overt the period.

Table 5. Land cover transition matrix 2000 to 2005 in hectares and percentages

\begin{tabular}{|c|c|c|c|c|c|}
\hline \multicolumn{6}{|c|}{$2005 \downarrow$} \\
\hline $2000 \rightarrow$ & Tree & Shrub grass & $\begin{array}{l}\text { Bare } \\
\text { ground }\end{array}$ & Urban & Total (2000) \\
\hline Tree (ha) & $\begin{array}{c}67,868 \\
(13.4) \\
{[67]}\end{array}$ & $\begin{array}{c}20,608 \\
(4.1) \\
{[20]}\end{array}$ & $\begin{array}{c}7,175 \\
(1.4) \\
{[7]}\end{array}$ & $\begin{array}{c}5,132 \\
(1) \\
{[5]}\end{array}$ & $\begin{array}{c}100,782 \\
(19.9)\end{array}$ \\
\hline Shrub grass (ha) & $\begin{array}{c}10,600 \\
(2.1) \\
{[8]}\end{array}$ & $\begin{array}{c}65,999 \\
(13.1) \\
{[48]}\end{array}$ & $\begin{array}{c}57,911 \\
(11.5) \\
{[42]}\end{array}$ & $\begin{array}{c}4,116 \\
(0.8) \\
{[3]}\end{array}$ & $\begin{array}{c}138,625 \\
(27.5)\end{array}$ \\
\hline Bare ground (ha) & $\begin{array}{c}2,456 \\
(0.5) \\
{[1]}\end{array}$ & $\begin{array}{c}58,200 \\
(11.5) \\
{[24]}\end{array}$ & $\begin{array}{c}183,574 \\
(36.3) \\
{[74]}\end{array}$ & $\begin{array}{c}2,536 \\
(0.5) \\
{[1]}\end{array}$ & $\begin{array}{c}246,766 \\
(48.8)\end{array}$ \\
\hline Urban (ha) & $\begin{array}{c}2,602 \\
(0.5) \\
{[14]}\end{array}$ & $\begin{array}{c}5,107 \\
(1) \\
{[28]}\end{array}$ & $\begin{array}{c}5,158 \\
(1) \\
{[28]}\end{array}$ & $\begin{array}{l}5,372 \\
(1.1) \\
{[29]}\end{array}$ & $\begin{array}{c}18,239 \\
(3.6)\end{array}$ \\
\hline Water (ha) & 325 & 229 & 165 & 112 & 831 \\
\hline Total (ha) & $\begin{array}{r}83,852 \\
(16.5)\end{array}$ & $\begin{array}{c}150,142 \\
(29.7)\end{array}$ & $\begin{array}{c}253,982 \\
(50.2)\end{array}$ & $\begin{array}{c}17,268 \\
(3.4)\end{array}$ & $\begin{array}{c}505,244 \\
(100)\end{array}$ \\
\hline $\begin{array}{c}\text { Swap } \\
\text { Net Gain by } 2005\end{array}$ & $(6.4)$ & $\begin{array}{c}(28.8) \\
(2.2)\end{array}$ & $\begin{array}{l}(25) \\
(1.4)\end{array}$ & & \\
\hline Net lost by 2005 & (3.4) & & & $(0.2)$ & \\
\hline
\end{tabular}

Note: The values in the circular bracket are percentage values of the area of study, and values in square bracket are percentage values convert overt the period. 


\subsection{The Perception of Environmental Change in the Study Area}

In all the locations where interviews were conducted, there was the perception that their surroundings had changed in the last 30 years. They felt that the increase in family size had led to the need for additional farm land which had affected the extent of the woodland. At Gammel, a town in the north eastern corner of the study area in the Gamawa-Jakusko plain the loss of the wilderness was associated with an increase in sand deposition providing some supporting evidence for the process of desertification. The perception of the changes in the Fadama was derived from the settlements in the immediate neighbourhood of the Fadama because no settlements exist within the Fadama itself. Generally the people living in the neighbourhood of the Fadama witnessed the opening of new farmland in the Fadama by people coming from bigger towns like Potiskum, and a lot of people coming to rent land for dry season farming, the situation often leading to conflict among the farmers and the cattle grazers over access to water. In places like Yaba, Gada and Dakidau in the neighbourhood of the Fadama experience annual immigration of fishermen and dry season farming with the rainy and dry seasons, respectively. Some respondents felt that there were weaknesses in the enforcement of the laws (since there were government officials on ground to restrict tree cutting) that controls the cutting of trees.

In the north of Potiskum and Gamawa-Jakusko plains the people complained of degradation of land as it related to farm yield. The people around Gammel in the Gamawa- Jakusko felt the deposition of sand and drought (or shorter rainy seasons) affected their yield, the people in the northern part of Potiskum plain felt the land was losing its nutrient value. This condition had caused some people to temporarily migrate during the rainy season to areas further south such as Gombe and for some people to abandon farming in order to pursue other, non farming ventures in Potiskum town. In these areas, many villages had to import their wood (fuel) from the southern part of the study area, this meant a great change to them because they were getting their supply of wood from their backyards.

The areas in the neighbourhood of Potiskum such as Firi and Tikau felt that the changes in wilderness had occurred much earlier than the 30 years ago. The changes seen in this area are rather due to the expansion of the town. The expansion of the Potiskum town in the east could partly be explained by the migration of people from northern areas coming to the town along the major road.

\section{Discussion and Conclussions}

The process of estimating land cover change involved the creation of reference data to conduct supervised classification. The classification was undertaken by both parallelepiped and maximum likelihood methods for the three years (1986, 2000 and 2005). The estimates of the area covered by each of the land covers were derived from pixel counting and a confusion matrix produced in order to show the accuracy of the estimates. Changes in the land cover were computed in accordance with Pontius et al. (2004).

The process of creating reference data was found to be a costly aspect of the procedure, even when one has facilities available such as the global position system (GPS) and high resolution images. Thus planning a supervised classification that will involve field survey in some parts of Africa which do not have current topographic maps may require greater allocation of time and resources than would be needed in Europe, for example. An alternative would be to conduct the field survey using aerial reconnaissance (Sannier, 2000). In spite of the difficulties, all of the 50 samples were successful surveyed from April to June before the rain began 2006.

A new estimation of land cover that related to tree, shrub grass, and bare ground and urban was derived from the classification of the 1986, 2000 and 2005 images. The four land cover categories chosen provided data suitable for the inventory of the major land covers and habitats, the assessment of forestry degradation (including wilderness), grazing land, expansion of bare ground (which is directly related to cropland), and the identification and expansion of the urban areas. The data is suitable in spite of the uncertainties in especially the estimation of the shrub grass could be useful for development of policy that will mitigate environmental problems such as degradation, sustainable utilisation of natural resources, planning, and execution and monitoring of such policy. For example, with this data we could plan the reversal of the loss of tree and evaluate the progress of such policy. The data however is limited to the dry season. Further research is required to determine the characteristics of land cover during the rainy season (June to September), using any available cloud free imagery. This has the potential of providing agricultural data as it will show which areas of the bare ground are cultivated.

The tee and bare ground land covers assessed indicated high percentage of persistence (the diagonal values in the brackets). In general and within the two periods, the tree land cover tends to reduced and the bare ground increased. There tends to be lower and decreasing swapping of the tree $(9.8 \%$ in $1986-2000$ and $6.4 \%$ 2000-2005), a further evidence of reduction in tree land cover. However there is high swapping in the bare 
ground, and high conversion between bare ground and shrub grass, these also relate to the uncertainties associated with their classification and the dominance of the two land covers.

The dynamics of land cover in the north east of Nigeria demonstrated in this research agrees in general with the perception of changes occurring in the area amongst the resident population. The group interviews conducted across the study area as to how people perceived changes in their environment in the last 30 years affirmed the $1.5 \%$ and $3 \%$ loss of tree between 1986 and 2000 and 2000 and 2005 (Tables 2 and 3). It also confirmed the increase in bare ground of $6 \%$ and $1 \%$ between 1986 and 2000 and 2000 and 2005.

The respondents to the interview generally felt that increase in population leads to the need for agricultural land and living space, degradation of agricultural land yield has further implications on: loss of plant and animal species, loss of yield, temporary migration and conflicts over farmlands and water resources. Increase in agricultural land and living correspond to increase in bare ground, since the time of imaging of the study are falls during the dry season when there are no farming activities.

A further analysis is required to connect the way the land is used with the changes evident from the image classifications. This will precisely define the process of land change occurring based on land use and local climatic variability in the context of global or regional change (such as by Lambin et al., 2006).

The land cover change occurring in the north eastern Nigeria indicated that over $60 \%$ of all the land cover remained unchanged. The second type of land cover change evident was changes in the location of the land cover. This second dimension of change is evidence of the dynamism in the land cover resulting in the negative loss of the tree and the increase and dominance of the bare ground. The shrub grass tends to relate with bare ground because the high inter conversion between them, providing further evidence for the increase in bare ground. This further agrees with the perception of the people living in the area, making the need to reverse the impact of the change necessary. The local need supports the global call for action against climate change requiring action at local, national and global levels. This work provides an effort in that direction. While providing estimates of land cover change that has occurred, it has demonstrated the uncertainties that attend such endeavours. The impact of the changes occurring presented in terms of loss of certain species of plant and animals, degradation of land and migration.

Further work is required to link the land cover measurements of the research and the precise measurement of people's perception and land use and how transition could be predicted considering the uncertainties in the classification.

\section{References}

Abdalla, J. D. (1994). The evaluation of Satellite imagery in a geographic information system (GIS) for monitoring land cover changes in semiarid area of north-eastern Nigeria (Unpublished doctoral dissertation). Cranfield University, United Kingdom.

Alrababah, M. A., \& Alhamad, M. N. (2006). Land use/cover classification of arid and semi-arid Mediterranean landscapes using Landsat ETM. International journal of remote sensing, 27(13), 2703-2718. http://dx.doi.org/10.1080/01431160500522700

Chen, F., Wang, C., \& Zhang, H. (2007). Automatic matching of high-resolution SAR images. International Journal of Remote Sensing, 28(16), 3665-3678. http://dx.doi.org/10.1080/01431160601034878

Climate Change and Carbon Finance. (2008). A UNEP-UNDP-UNCCD Technical Note for Discussions at CRIC 7, Istanbul, Turkey - $\quad 03-14 \quad$ November, 2008. Retrieved from http://www.unep-wcmc.org/climate/pdf/Carbon\%20in\%20drylands.pdf

Congalton, R. G., \& Green, K. (1999). Assessing the accuracy of remotely sensed data: principles and practices. CRC Press, United States.

Coppin, P., Jonckheere, I., Nackaerts, K., Muys, B., \& Lambin, E. (2004). Review ArticleDigital change detection methods in ecosystem monitoring: a review. International journal of remote sensing, 25(9), 1565-1596. http://dx.doi.org/10.1080/0143116031000101675

Disaster Monitoring Constellation (DMC). ( 2007). Radiometric correction of the DMC.

FAO-Africover. (2007). LCCS GLOSSARY - $\quad$ Tanzania. Retrieved from http://www.africover.org/download/documents/MADE/LCCSglossary_tz.pdf 
Foley, J. A., Coe, M. T., Scheffer, M., \& Wang, G. (2003). Regime shifts in the Sahara and Sahel: interactions between ecological and climatic systems in Northern Africa. Ecosystems, 6(6), 524-532. http://dx.doi.org/10.1007/s10021-002-0227-0

Foody, G. M. (2002). Status of land cover classification accuracy assessment. Remote sensing of environment, 80(1), 185-201. http://dx.doi.org/10.1016/S0034-4257(01)00295-4

Foody, G. M. (2006). The evaluation and comparison of thematic maps derived from remote sensing. In M. Caetano \& M. Painho (Eds.), 7th International Symposium on Spatial Accuracy. Assessment in Natural Resources and Environmental Sciences.

Gallego, F. G. (1995) Sampling frames of square segments. European Commission, Brussels.

Goes. (2005). Pre-water audit for the Komadugu-Yobe river basin, northern Nigeria and southern Niger (Unpublished Report). Nigeria.

Jensen, J. R. (2000). Remote Sensing of the Environment. London: Prentice-Hall, Inc.

Lambin, E. F., Geist, H., \& Rindfuss, R. R. (2006). Introduction: Local process with global impact (1st Ed.). Berlin Heildelberg: Springer.

Lambin, E. F., Turner, B. L., Geist, H. J., Agbola, S. B., Angelsen, A., Bruce, J. W., ... Xu, J. (2001). The causes of land-use and land-cover change: moving beyond the myths. Global environmental change, 11(4), 261-269. http://dx.doi.org/10.1016/S0959-3780(01)00007-3

Landsat.org. (2004). Landsat TM and ETM data. Retrieved from http://www.landsat.org/ortho/index.htm

Lawan, A. I. (1996). The application high spatial resolution satellite data for land use and land cover mapping and inventory in north east Nigeria (Unpublished doctoral dissertation). Cranfield University, United Kingdom.

Leica Geosystems Geospatial Imaging LLC. (2005). Field Guide. Leica Geosystems Geospatial Imaging LLC, United Kingdom.

Lillesand, T. M., Kieffer, R. W., \& Chipman J. W. (2000). Remote Sensing and Image Interpretation. In John Wiley \& Sons (Eds.). United State: Inc.

Milligan, S., \& Binns, T. (2007). Crisis in policy, policy in crisis: understanding environmental discourse and resource-use conflict in northern Nigeria. The Geographical Journal, 173(2), 143-156. http://dx.doi.org/10.1111/j.1475-4959.2007.00231.x

Milligan, S., \& Binns, T. (2007). Crisis in policy, policy in crisis: Understanding.

Moran, E. F., Skole, D. L., \& Turner, B. L. (2004). The Development of the International Land-use and Land-cover change (LUCC) Research Program and its Links to NASA"s Land-cover and Land-use Change (LCLUC) Initiatives. Nitherlands: Kluver Academic Publication.

National Space Research Development Agency (NASRDA). (2008). Retrieved April 3, 2008.

Onyewotu, L. O. Z., Stigter, C. J., Abdullahi, A. M., Ariyo, J. A., Oladipo, E. O., \& Owonubi, J. J. (2003). Reclamation of desertified farmlands and consequences for its farmers in semiarid northern Nigeria: a case study of Yambawa rehabilitation scheme. Arid Land Research and Management, 17(1), 85-101. http://dx.doi.org/10.1080/15324980301590

Pan, C., Zhang, Z., Yan, H., Wu, G., \& Ma, S. (2008). Multisource data registration based on NURBS description of contours. International Journal of Remote Sensing, 29(2), 569-591. http://dx.doi.org/10.1080/01431160701294687

Pontius Jr, R. G., Shusas, E., \& McEachern, M. (2004). Detecting important categorical land changes while accounting for persistence. Agriculture, Ecosystems \& Environment, 101(2), 251-268. http://dx.doi.org/10.1016/j.agee.2003.09.008

Pontius, R. G. (2000). Quantification error versus location error in comparison of categorical maps. Photogrammetric Engineering and Remote Sensing, 66(8), 1011-1016.

Ramankutty, N., Graumlich, L., Achard, F., Alves, D., Chhabra, A., DeFries, R. S., ... Turner II, B. L. (2006). Global land-cover change: Recent progress, remaining challenges. In E. F. Lambin \& H. J. Geist (Eds.), Land-use and land-cover change: local processes and global impacts (pp. 7-40). Berlin Heidelberg: Springer. http://dx.doi.org/10.1007/3-540-32202-7_2 
Richard, J. A., \& Jia, X. (1999). Remote sensing digital image analysis. Germany: Springer-Veerlag. http://dx.doi.org/10.1007/978-3-662-03978-6

Sannier, C. A. D. (2000). Strategic monitoring of crop yield and range condition in southern Africa with remote sensing (Unpublished doctoral dissertation). Cranfield University, United Kingdom.

Schowengerdt, R. A. (2007). Remote sensing models and methods for image processing. United States: Elsevier.

Shonenka, E. (1997). Vision 2010. Nigeria: Federal Republic of Nigeria.

Stow, D., Coulter, L., \& Baer, S. (2003). A frame centre matching approach to registration for change detection with fine spatial resolution multi-temporal imagery. International Journal of Remote Sensing, 24(19), 3873-3879. http://dx.doi.org/10.1080/0143116031000152309

Taylor, J. C., Sannier, C. A. D., Delince, J., \& Gallego, F. G. (1997). Regional crop inventories in Europe assisted by remote sensing: $1988-1993$. European Commission, Brussels.

Trumpet, K., Ravilious, C., \& Dickson, B. (2008). Carbon in Drylands: Desertification, Climate Change and Carbon Finance.

Wagenseil, H., \& Samimi, C. (2006). Assessing spatio-temporal variations in plant phenology using Fourier analysis on NDVI time series: results from a dry savannah environment in Namibia. International Journal of Remote Sensing, 27(16), 3455-3471. http://dx.doi.org/10.1080/01431160600639743

Yobe State Ministry of Agriculture. (2005). Rainfall data.

\section{Copyrights}

Copyright for this article is retained by the author(s), with first publication rights granted to the journal.

This is an open-access article distributed under the terms and conditions of the Creative Commons Attribution license (http://creativecommons.org/licenses/by/3.0/). 